\title{
Industrial relations: will they survive the Labour Relations Act 1987?
}

\author{
John Haigh*
}

To venture predictions in the field of industrial relations is unwise. Many if not most predictions will be wrong, and these tend to be remembered by industrial law commentators. Having said that, it is the writer's view that the heyday of the use of unjunctions in industrial law has been and gone. Their future use is likely to be considerably reduced. To support this proposition, a brief examination of the use of interim injunctions in industrial law is necessary.

\section{Background}

In the main, it has been the employers who have utilised the High Court's power to issue interim injunctions. The availability of the interim injunction as a remedy in industrial law has been present for a long time but its use in the past has been voluntarily curtailed by the employers themselves.

The reason for the limited use of the interim injunction is far from altruistic. In the 1970s and the early $1980 \mathrm{~s}$, when the strength of certain unions was at its peak, employers were only too well aware of the fact that a success in court did not guarantee a success on the shop floor. Unions and their officials tended to have long memories when the law (outside the Industrial Relations Act 1973) was utilised as a weapon by the employer. The ramifications of winning the battle in court, could mean the loss of the war as such, in the workplace. This was particularly so when union solidarity enabled the successful employer litigant to be attacked from another direction, by members of a separate union whose labour was essential to that employer's industry.

The use of injunctions was by and large a last resort by the employer. The High Court (confirmed by the Court of Appeal) always retained its jurisdiction to intervene when the legislative code designed to govern and resolve industrial disputes failed the employer in terms of the machinery available to end what on the face of it was unlawful strike action. However, despite the "last resort" factor, injunctions as a remedy to resolve industrial conflicts have been far more utilised over the past few years. As the use of injunctions by employers grew, so correspondingly did the view of unions that the law was largely one-sided, unnecessarily protecting the employer from a union's only strength, its withdrawal of labour.

So, on one hand, employers claimed that the Industrial Relations Act 1973 did not provide the machinery to prevent allegedly illegal strikes and similarly did not have the power to issue injunctions or compliance orders requiring a return to work. On the other hand. the unions (or at least some of them) took a somewhat cynical view of the law. Steps were often taken to circumvent the significant restraints imposed by the law on the withdrawal of labour. The result of this conflict was the increased use of injunctions to resolve strike action (or impending strike action) which the employer felt could not be resolved in the Arbitration Court. 


\section{Injunction proceedings as a weapon}

Injunction proceedings in the High Court have been a successful weapon in the industrial law arena. A hardening of attitudes by employers over the past 2 years or so, has seen something of a flurry of applications to the High Court. This appears to have coincided with a view by the employers that the union movement is on a downturn in terms of strength and financial resources; hence the more frequent and earlier use of injunctions. Further, as the employers perceived a lessening of the threat of union striking back, so they moved more frequently to the High Court for an early resolution of difficult disputes. The downturn in the economy, diminishing strength of certain unions, and the growth of unemployment, meant that the threat of retaliatory action in the workplace had diminished. Certain employers therefore seized upon the apparent advantages of utilising the High Court and in particular sought interim injunctions.

The advantages of applying to the High Court for an interim injunction were many. They included:

1. The employer's ability to pay legal costs was far greater. The limited resources of unions acted to encourage some employers.

2. The High Court had only to decide whether or not there was a serious question to be answered, and then determine the issue on the balance of convenience. As there was often a considerable amount of money at stake, frequently the Courts found that there was a serious question, and that the balance of convenience lay with avoiding a continuing monetary loss.

3. To even begin to fight an application for an interim injunction, the union was required to give an undertaking to meet any damages sustained if the interim injunction was not granted but judgment was subsequently entered against the union at the full hearing. This was a particularly onerous requirement for many unions, and often lead to capitulation and an unwillingness to fight the application.

By and large then, the odds were stacked against a union. The threat of continuing monetary losses, and the constantly used claims that the strike action would result in job losses, frequently persuaded the High Court that the balance of convenience (assuming a serious question had been found to have existed) lay in favour of an interim injunction being granted.

Employers however did come unstuck on occasions, particularly when confronted with High Court judges who recognised that industrial disputes were infrequently resolved in the labyrinths of the High Court. Such judges (who admittedly were few in number) would enter into the fray acting as de facto mediators, in an attempt to resolve the dispute without resource to the issuing of an interim injunction. This would often result in a multitude of adjournments but the quasi-mediation role of the High Court was frequently successful in avoiding continuing confrontations which could have resulted from a court order requiring a return to work. Hence the question of which judge heard an application for an interim injunction became of critical importance.

Whilst every application for an interim injunction had to be accompanied by a substantive claim, more often than not this substantive claim would be abandoned or left in abeyance on the basis that the interim order resolved the immediate dispute. A notable exception to this general rule was seen in the case of Nauru Local Government Council v New Zealand Seamens $I U W$. This case demonstrated inter alia that where an employer had no fear of retaliatory action in the future, it could and would pursue a union to the bitter end.

There were also employers who for whatever reason were prepared to obtain judgment if necessary by default, probably to give clear notice to the particular union. that it would take all steps to prevent allegedly illegal strike action, and all steps necessary to recoup losses incurred. One such action where judgment was obtained by default in the High Court and subsequently set aside, is still before the High Court in terms of the substantive claim for damages. (See Ford Motor Company Ltd v the Northern Storepersons Union and Others) An interim injunction which accompanied this substantive claim was abandoned before being heard.

The 1986 wage round saw probably the high point of the use of industrial injunctions, as a result of what appeared to be a decision of the Employers Association to go on to the offensive. Towards the end of 1986 there was a marked increase in the use of injunctions by employers. including somewhat dubious allegations that strike action by certain unions during the wage round was illegal. Often the desired effect was achieved. Many of the smaller unions, without financial resources, found themselves compromised by the requirement to give undertakings. and by the considerable costs necessary to fight the application for an interim injunction and any 
substantive claim for damages. The result was the abandoning of the alleged strike action before any court hearing. often in consideration of the substantive claim for damages being withdrawn.

The use of injunctions then was a successful weapon. In by far the majority of cases the action being sought to be restrained ceased either as a result of the issuing of the proceedings in the High Court, or because of the granting of an interim injunction preventing the continuance of such action.

\section{Where now with the Labour Relations Act 1987?}

In the midst of the increased use of injunctions arrives the Labour Relations Act 1987. This of course provides exclusive jurisdiction to the Labour Court to grant injunctions arising from a strike or lockout or a threatened strike or lockout. On the face of it then, the remedy still exists. and is alive and well in the hands of the Labour Court. But the reality may be different. The key point is contained in s 243(3) of the Act. In summary this states that the Court shall dismiss applications for interim injunctions where the strike or lockout is lawful in terms of $s 233$ of the Act.

This is a significant restriction on the obtaining of interim injunctions. When the High Court had jurisdiction, it only had to consider whether or not there was a serious question to be tried, and where the balance of convenience lay. In Tip Top Ice Cream Company Ltd v Northern Clerical Workers IUW and Others. His Honour, Mr Justice Thorp, concluded that the High Court need only determine whether or not a prima facie case existed alleging an unlawful or tortious action by the union before turning to the question of the balance of convenience. Thus the obtaining of an interim injunction was not dependent upon a conclusive finding of unlawfulness, or the committing of a tortious wrong.

The test now is much higher. The Court even on its volition must consider the issue as to whether or not the strike is lawful, before reaching the point of determining whether an application for an injunction should be granted. Accordingly, it is the writer's view that the use of injunctions, by employers or unions will be considerably reduced.

As a remedy it is likely to be replaced by the use of compliance orders. The vastly sirengthened powers of the Labour Court in this area are set out in s 207 of the Act. It was obviously intended by the legislature, that the Court would be given real teeth in terms of penalties (including imprisonment) and jurisdiction for the issuing of compliance orders. Such powers may further contribute to the death knell of injunctions in the area of industrial law.

\section{Conclusions}

In losing the jurisdiction of the High Court to grant injunctions, employers in particular have lost the somewhat dubious right to allege acts of unlawfulness, or tortious wrongs resulting in the issuance of interim injunctions, without a proper and detailed consideration of the substantive allegations. That loss, with respect, is to be welcomed. Compliance orders will supersede injunctions as the most effective remedy to prevent ongoing breaches of industrial awards or agreements.

\section{List of cases}

Ford Motor Co Ltd v Northern Storepersons and Others Unreported High Court. Auckland, CP $1140 / 86$

Nauru Local Government Council v New Zealand Seamens IUW CA 63/83.

Tip Top Ice Cream Co Ltd v Northern Clerical Workers IUW and Others M 1171/86, Auckland High Court. 